This item was submitted to Loughborough's Research Repository by the author.

Items in Figshare are protected by copyright, with all rights reserved, unless otherwise indicated.

\title{
Refeudalisation revisited: The destruction of deliberative democracy
}

PLEASE CITE THE PUBLISHED VERSION

https://doi.org/10.1080/13183222.2017.1418993

\section{PUBLISHER}

Taylor and Francis @ EURICOM

\section{VERSION}

AM (Accepted Manuscript)

\section{PUBLISHER STATEMENT}

This is an Accepted Manuscript of an article published by Taylor \& Francis in Javnost - The Public Journal of the European Institute for Communication and Culture on 09 Feb 2018, available online: 09 Feb 2018

\section{LICENCE}

CC BY-NC-ND 4.0

\section{REPOSITORY RECORD}

Murdock, Graham. 2019. "Refeudalisation Revisited: The Destruction of Deliberative Democracy”. figshare. https://hdl.handle.net/2134/32365. 
Refeudalisation Revisited: The Destruction of Deliberative Democracy Graham Murdock

Professor of Culture and Economy University of Loughborough Javnost-The Public DOI:10.1080/13183222.2017.1418993.

In 1962 Bernard Crick., published In Defence of Politics. Aimed squarely at conceptions of politics organised around winner-takes-all platforms it mounted a spirited defence of negotiated settlement as the indispensable basis for a plural society (Crick 1962). As a recent commentary on Crick notes however, to operate successfully "the art of political horse- trading" has to be firmly grounded in "decent information, civility and conciliation" (The Economist 2017:11)

These essential conditions for democratic politics were explored in another book, published in the same year, Jurgen Habermas's The Structural Transformation of the Public Sphere (Habermas 1991). Both men had witnessed the devastating impact of Hitler's politics of violence and both believed passionately in strengthening the twin pillars of democratic participation, voting and voice, representation and deliberation.

Habermas sets out to trace the rise and decline of the critical public sphere, understood as the web of direct and mediated spaces where open deliberation on contentious issues is conducted in good faith, highlighting the challenge to this ideal presented by the rise of "publicity merely staged for manipulative ends" [Habermas 1991:232] In a striking phrase, he characterises this as "a refeudalization of the public sphere" [opcit: 195], repositioning people as subjects, spectators at pageants of power, rather than citizens collaborating in constructing a collective future.

He sees contemporary politicians following the feudal monarchs who promoted carefully crafted public personas through portraits on coins and spectacular events, displaying "a showy pomp" [p195] designed to create "the kind of aura proper to personal prestige" [Habermas 1991:195]. But 
those seeking power in democratic polities cannot claim a divine right to rule. They need a popular mandate. To secure this, Habermas argues, they borrow the kingly practice of presenting themselves as servants of 'the people', battling enemies without and within, focusing their appeals on particularly on " that minority whose state of mind is symptomatically revealed, according to survey researchers, in terms of an average vocabulary of five hundred words" [op cit:217].

In pursuit of this goal Habermas observes, they by-pass established channels of mediated communication and rely on direct modes of address with the result that "press and radio, "deployed in the usual manner", have practically no effect: within the framework of the manufactured public sphere" [Habermas 1991:217]. He sees the substation of emotion for evidence based argument in populist appeals as "especially manipulative" and patently self-serving since it calls for "predictable reactions without ... placing any obligation whatever " on those seeking "secure plebiscitary agreement" [opcit :217]. Once consent is obtained they can pursue interests concealed in their public discourse.

Despite this bleak account Habermas concludes that "The outcome of the struggle between a critical publicity and one merely staged for manipulative purposes remains open" [Habermas 1991:235] . The election of Donald Trump and the Brexit referendum arguably point to a more pessimistic conclusion.

The regression, from citizens to subjects, is reinforced under current conditions by the business model operated by the internet majors .To log on is to be enlisted as a labourer working in digital fields owned by the new feudal landlords who appropriate whatever data surplus is produced,

Before writing The Structural Transformation of The Public Sphere Habermas worked at the Frankfurt Institute for Social Research and his analysis builds on the research produced by the Institute's members as they struggled to analyse the corruption of deliberative democracy, initially in Germany with the collapse of the Weimar Republic and later in the United States. Their work remains an indispensable resource for understanding contemporary conditions.

Lessons from Weimar: The Nazi Shadow. 
In January 1933 Hitler was appointed Chancellor and following the burning of the parliament building, introduced an Enabling Act granting him absolute power. A Marxist oriented institute had no future in Nazi Germany .It was closed and the building occupied by the Gestapo. Anticipating this the offices had been moved to Geneva and in 1935 relocated to New York. Before these forced exiles however, Max Horkheimer, who had assumed the directorship in 1930, had established a significant body of research exploring the social and psychological roots of the authoritarianism underpinning Hitler's popular support.

The first major project was a questionnaire distributed to around three thousand workers. Drawing on the psychoanalytic training of the study's main researcher, Eric Fromm, answers to useable replies were searched for key words and phrases that suggested underlying dispositions. Although only ten per cent of respondents could be classified as firmly committed to authoritarianism, only fifteen per cent were strongly antauthoritarian, leaving three quarters undecided and open to persuasion. Fromm resigned soon afterwards and plans to publish the results never came to fruition. A summary did appear however in the Institute's more general analysis of the social and psychological roots of authoritarianism published in 1936 as Studies on Authority and the Family which, among other things, presented popular compliance as a response to the social and cultural dislocation generated by economic depression.

An earlier study, of routine white collar workers in Berlin , by the leading journalist, Siegfried Kracauer, had concluded that economic development had demolished "The house of bourgeois values and feelings in which they used to live ...leaving them "spiritually homeless" "(Kracauer 1998:88). In a later analysis he saw this vacant cultural space colonised by cinema narratives crafting a "national epic [that] dwelt upon Prussia's humiliation [and] her future redemption" led by an inspired Fuhrer (Kracauer 1947: 263). There were counter narratives but as he noted "in the conflict of antiauthoritarian and authoritarian dispositions, the odds are against the former" (op cit:271). This was partly because social democratic programs were associated with decline and dislocation ,an argument forcefully restated by Franz Neumann, who joined the Frankfurt Institute in the United States .In his magisterial analysis of Hitler's regime, Behemoth, published in 1944, he identified the Social 
Democratic Party's failure to "symbolize a vital and realistic policy" as a major contributing factor to her Nazi's popular appeal (Neumann 1944:437)

The context has changed but recent developments have invested this arguments with new relevance. The campaigns of Donald Trump in the United States and the Brexiteers in Britain spoke to the lived experience of three decades of declining living standards and the perceived failure the Democratic Party and New Labour to effectively contest the neo liberal ascendency that had created widespread insecurity and immiseration. Their campaigns also articulated deep seated fears of declining national power and respect on the world stage, with Trump promising to 'Make America Great Again' and the leading Brexiteer, Boris Johnson exhorting Britain to 'Let that Lion Roar', a reference to the emblem of royal power in England since Norman times. In understanding the rhetorical building blocks on which these appeals were constructed and the communication strategies employed to promote them the work conducted by members of the Frankfurt group, in exile in the United States, continues to provide an indispensable starting point for analysis.

\section{Dispatches from the United Sates: Democracy and Demagoguery}

Hitler's preferred modes of public address were expressly designed to establish a direct connection to his supporters. The meticulously orchestrated night-time mass rallies with their dramatic lighting and seas of waving flags offered a spectacular stage for his rhetorical performances As Walter Benjamin, a long- time associate of the Frankfurt Institute, noted, they were integral to a promotional apparatus that introduced "aesthetics into political life" offering spaces of "expression while preserving property "( Benjamin 1970:24 ). Those unable to attend could listen to the speeches on the radio, a medium whose potential for constructing an illusion of personalised communication Hitler had immediately grasped.

He was not alone. For over a decade, from 1933 to 1944, the President of the United States, Franklin D Roosevelt, regularly addressed the nation on radio explaining the thinking behind his policies reproducing informal talk around the domestic dinner table, an intended intimacy anchored by the title, 'Fireside Chats'. The commercial and competitive basis of American radio however, also opened it to a range of right-wing populist 
platforms. Their strident presence suggested that am established democracy might harbour the same authoritarian undercurrents that supported Fascism. Morris Janowitz who analysed the radio speeches of the right -wing populist politician Gerald Smith was in no doubt that he was "a dangerous manifestation of something deep in the American tradition" (Janowitz 1944: 84). In a rhetorical manoeuvre familiar from the Trump campaign Smith presented himself as "the under-dog candidate harassed and persecuted" by "newspaper lies" who would stand up for "the common people" against the corruption and deceit of politicians and bureaucrats in Washington (Janowitz 1944: 90-91) . Earlier in his career, Smith had supported the most successful right-wing radio commentator of the inter-war years, Father Charles Coughlin whose weekly broadcasts over a national network of independent stations in the mid 1930s had a reach of over forty million. (see Kay,Ziegelmueller and Minch 1998) His speeches were analysed in detail in a pioneering study by Alfred and Elizabeth Lee published in 1939 (Lee and Lee 1939) .

The Frankfurt group contributed to debate on authoritarian populism's capacity to subvert the democratic process with detailed analyses of a range of populist agitators and surveys of their popular support.

Theodore Adorno had come to New York to work with Paul Lazarsfeld on the series of studies of the radio industry and its audiences. His initial focus was on music radio but he was struck by how similar the rhetorical devices employed by right wing commentators were to Hitler's. When Horkheimer moved to California on health grounds Adorno joined him and began analysing the broadcasts of Martin Luther Thomas who had a strong base in evangelical Christianity (Adorno 2000). Although the enemies Thomas' identified in his speeches were resolutely secular and located in the here-and-now, the promise that the faithful could be 'born again' if they renounced the named devils and all their works and embraced the true path he outlined, drew heavily on the fundamentalist world view .Adorno's analysis remained unpublished at the time, but research on a wider sample of right wing appeals led by another member of the Frankfurt group, Leo Lowenthal, was published in 1949, under the title Prophets of Deceit: A Study of the Techniques of the American Agitator (Lowenthal and Guterman 1949). 
The speeches analysed revolved around two fundamental oppositions, between 'us' and 'them' and past and present, animated by an idealised national narrative of a society securely anchored in a common culture and shared values. This construction automatic labels "foreigness" as disruptive and corrosive and denounces any "plans to let new immigrants enter the country" (Lowenthal and Guterman 1949:50). These external threats were accompanied by visions of a fundamental breakdown of trust between rulers and ruled that played on popular suspicions that many elected representatives were in the pocket of lobbies catering to special interests.

As the Frankfurt studies make clear however, authoritarian populism cannot be understood simply as a discourse promoting a particular world view. As Adorno noted, "Hitler was liked, not in spite of his cheap antics, but just because of them" (Adorno 1994:167). The American agitators he researched followed suit, aiming at "a performance reminiscent of the theatre" (op cit:166). "They give their admission-paying audience something between a tragical recital and a clownish pantomime-rather than a political speech. Discussion of political topics invariably serves them as an occasion for violent vituperation and seemingly irrelevant personal abuse" (Lowenthal and Guterman 1949:4). This studied "disregard for 'appropriate ways of acting in the political realm" (Moffitt and Tormey 2014:392) mobilises a common language of condemnation and shared emotions of anger and outrage so that speakers appear "like someone arising from its midst to express its innermost thoughts" (Lowenthal and Guterman 1949:5). Their proposed solutions "may seem incongruous and morally shocking, but are always facile, simple, and final" (Lowenthal and Guterman 1949:9)

\section{Profits of Deceit :Trump and Brexit}

Donald Trump , Boris Johnson, the central figure in the Vote Leave campaign, and Nigel Farage the driving force behind the alternative campaign based around the UK Independence Party (UKIP) are all master showmen with distinctive performance styles. 
For the first fourteen seasons of its run on prime-time network television, Trump compered reality show The Apprentice with its signature catchphrase, 'You're Fired'. This exposure helped cement his claim to business acumen and decisiveness, but his performance style owes more to his association with the contests staged by World Wide Wresting Entertainment (WWE). As Roland Barthes famously noted, "The virtue of all-in wrestling is that it a spectacle of excess "(Barthes 1973:15). The 2007 WWE 'Battle of the Billionaires' ,which pitched a wrestler representing Trump against an opponent representing his rival Vince McMahon, was a perfect demonstration. Following McMahon's defeat Trump pretended to punch him while he was lying on the floor, shaved his head and showered the audience with dollar bills. As Naomi Klein has argued "His carefully nurtured feuds with other candidates" during his election campaign " were pure pro wrestling, especially the way he handed out insulting nicknames [and] played ringmaster at his rallies , complete with over-the-top insults ...directing the crowd's rage at the arena's designated villains" (Klein 2017:52).

Johnson and Farage are less histrionic but both have carefully orchestrated performative personas, Johnson as a dedicated patriot with a penchant for clowning and Farage as just an 'ordinary bloke', an image he burnishes at every opportunity by insisting on being photographed in an English pub enjoying a pint of English beer. Johnson is more flamboyant. When the zip wire he was riding as part of the celebrations for a British gold medal at the 2012 Olympics, jammed, suspending him in mid-air, he took the opportunity to wave the two small national flags he was holding for the benefit of the crowd looking up anxiously from below. As Adorno observed, "agitators are taken seriously because they risk making fools of themselves" (Adorno 1994:166)

These performative styles have promoted populist motifs that Adorno and Lowenthal would readily recognise. Both Trump's 'America First' slogan and the Leave campaign's demand for Britain to 'Take Back Control' spoke to popular anxieties and resentments fuelled by deindustrialisation and the increased transnational flows of migrants generated by neo liberal globalization. In response, they proposed two simple solutions: reimposing control over national borders and regaining sovereignty over key decisions. 
Lowenthal and Guterman had identified the 'placeless' refugee as the "ideal model for irreconcilability" at the heart of populist constructions of social disruption and cultural erosion (Lowenthal and Guterman 1949:51). This motif occupied a central place in both the campaigns discussed here. Nigel Farage was photographed standing in front of a billboard poster depicting a packed column of refugees from Syria approaching the border with the European Union. The composition and placing reproduced exactly a sequence from a Nazi propaganda film warning against "the parasites who flooded Europe's cities after the last war" (Bartlett 2017). Under the heading 'Breaking Point ' the Ukip poster evoked the same threat declaring that 'The EU has failed us' and now was the time to "take back control of our borders". This same demand was central to Trump's campaign with repeated promises to build a wall along the Mexican border and subsequent attempts to capitalise on fears to jihadist attacks to ban citizens of named countries from entering the country.

Alongside demands to police national borders more forcefully both Trump and the Leave campaigns championed the reassertion of national sovereignty over key decisions affecting political and social life. No longer being subject to judgements in the European Court of Justice or to regulations introduced by European agencies was central to the case made for Brexit. For Trump putting 'America First' has entailed detachment from transnational agencies and agreements that impose obligations, most notably UNESCO and the Paris Climate Agreement.

'Taking back control' also has a hard economic edge. Claiming that free trade agreements signed by the US have disadvantaged domestic industry, Trump has withdrawn from the Trans Pacific Partnership Agreement. During the Leave campaign the coach transporting Boris Johnson around the country displayed the prominent message, 'We send the EU £350 million a week. Let's fund our NHS instead. Let's take back control". The figure was fictional but it spoke to the popular assumption that the relationship with the EU was a one-way street while posing as the saviour of the country's most admired institution, the National Health Service.

The Trump and Leave campaigns were successful but the margins of victory were relatively small. In Britain 51.89 percent of those voting in the 
referendum opted to leave the EU with 48.11 voting to stay. Hilary Clinton secured 2.9 million more popular votes than Trump but his victories in key states secured sufficient Republican nominations to the Electoral College, which makes the final decision, to give him $57 \%$ of the votes and the presidency. Faced with these slim margins both Trump and the British government ,led by Teresa May, have repeatedly reemphasized their popular mandate and claimed that anyone who seeks to criticise or impeded them is disregarding the expressed will of the people.

This opposition was dramatized in the starkest terms in November 2016 when the High Court in Britain ruled that the decision to trigger the process of leaving the EU required the consent of parliament. The following day the leading right of centre national daily, the Daily Mail, denounced the judges as 'Enemies of the People' .On the 19 April , the day after Teresa May had called a snap election hoping to increase her parliamentary majority, The Daily Mail, carried the headline 'Crush the Saboteurs'. Labelling opponents as 'saboteurs' and 'enemies' are classic populist constructions designed to reaffirm the absolute dividing lines between 'them' and 'us' and leaders who champions the 'people's' will and those seeking to deny it.

To ensure that parliamentary opponents are rendered powerless Mr May has sort to use the so-called Henry VIII powers that originated with the Statute of Proclamations of 1539 and which enable the prime minister to approve amendments to laws by executive action, a major move towards the restoration of feudal authority.

President Trump currently faces a similar impasse. Unable to progress his promised legislative agenda through the Congress and Senate, he has made extensive use of executive orders. By the end of his first hundred days in office he had signed a total of thirty two, more than any President since World War II. At the same time he has devoted considerable time and energy to shoring up his core base of support.

As noted earlier, Habermas saw mainstream press and radio "having "practically no effect within the framework of the manufactured public sphere" (Habermas 1991:215).Faced with criticism from mainstream news media Trump has dismissed them as sources of 'fake news' designed to disparage him and refuses to address them. After two 
hundred days in office he had held only one solo press conference , compared to Obama's nine and Clinton's eight at the same point. He can on support from right-wing internet sites led by the Breibart News Network, the self styled 'platform of the alt-right' but prefers to reach his supporters directly through mass rallies and posts on Twitter.

Between taking office and the end of September 2017, Trump had spoken at nine mass rallies in his heartlands of support, attracting audiences of between 6,000 and 15,000 . The populist performative skills displayed in his live appearances are matched by the immediacy of the vernacular speech of his Twitter posts. Between his inauguration and July 2017 he had posted over a thousand 'tweets' averaging 5.5 a day. With their grammatical mistakes and insults to opponents they mimic everyday arguments over current events in bars and workplaces and confirm Adorno's characterisation of right wing populist speech's provision of an "organised flight of ideas" in place of "discursive logic" (Adorno 1994:165). This communicative strategy produces a self- reinforcing circle with Trump's twitter posts and rally performances being taken up and amplified in the media outlets favoured by his supporters. In place of a public sphere open to diverse positions this process channels discussion into public sphericles (Gitlin 1998) or echo chambers in which information and argument selected according to a predefined position circulates with a closed space. The result is the destruction of deliberative democracy in which the attempted executive pre-emption of open debate in legislative chambers is matched by the subversion of the open deliberation required for the development of critical public opinion.

This process is amplified by Facebook's central role as a filtering mechanism directing news and comment to users' sites on the basis of profiles constructed from their on-line actvities. Both Trump's presidential campaign and the Leave campaign in Britain made extensive use of data analytics to micro manage the placing a publicity and appeals on Facebook, reinforcing the self-enclosure of political debate and its separation into mutually antagonistic camps.

As Habermas noted, the appeals that the architects of "the manipulated pubic sphere" devise to "secure plebiscitary agreement" place no "obligations whatever" on themselves (Habermas 1991:215). Both the Trump presidency and the push to uncouple Britain completely from 
European institutions are designed to reinforce a neo-liberal settlement that favours minimum regulation and restraint on business, relocates key decisions from legislative assemblies to corporate boardrooms, and continues to transfer income and wealth from the bottom to the top of the social scale. .

Even a cursory glance at the history of the Middle Ages however confirms that attempts to consolidate feudal rule were punctuated by periodic peasants' revolts and popular protests against perceived injustices and the arbitrary exercise of power. Contemporary processes of refeudalisation which aim to translate citizens into audiences in theatres of power, applauding performances on cue, are being met with new forms of refusal and resistance intent on restoring spaces and practices of open deliberation and cooperative action. The future of democratic politics, as an arena of principled bargaining in defence of ideals of justice, equality and communality will depend on their success.

\section{References}

Adorno, Theodore (1994) 'Anti-Semitism and Fascist Propaganda' in Theodore Adorno, The Stars Down to Earth and Other Essays in Irrational Culture.Londo.Routledge.

Adorno, Theodore (2000) The Psychological Technique of Martin Luther Thomas' Radio Addresses. Stanford CA. Stanford University Press.

Benjamin, Walter (1970) Illuminations. London.Fontana.

Barthes, Roland (1973) Mythologies.London. Paladin.

Bartlett, Evan (20170 'People are calling out Ukip's new anti- EU poster for for resembling 'outright Nazi propaganda'" Indy 100 https://www.indy100.com/article/people-are-calling-out-ukips-newantieu-poster-for-resembling-outright-nazi-propaganda--WkTYUB18EW [accessed Novmber 11th]

Crick, Bernard (1962) In Defence of Politics. Chicago. Chicago University press. 
Giltlin, Todd (1998) 'Public sphere or public sphericles?' in - Tmar Leibes and James Curran (eds) Media, Ritual and Identity.London. Routledge, pp 168-174.

Kay, Jack, Ziegelmueller,Georg and Minch, Kevin (1998) 'From Coughlin to Contemporary Talk Radio: Fallacies and Propaganda in American Popular Radio,Journal of Radio Studies, Vol 15, pp 9-21.

Klein, Naomi (2017) No is Not Enough: Debating the New Shock Politics. London. Allen Lane.

Kracauer, Sigfried (1947) From Caligari to Hitler: A Psychological History of the German Film. Princeton University Press.

Kracauer, Sigfried (1998) The Salaried Masses: Dutu and Distraction in Weimar Germany. London. Verso.

Habermas, Jurgen (1991) The Structural Transformation of the Public Sphere: An Inquiry into a Category of Bourgeois Society. Cambridge MA. The MIT Press.

Janowitz, Morris (1944) 'The Techniques of Propaganda for Reaction:Gerald L K Smith's Radio Speeces', Public Opinion Quarterly, Vol 8 (1) , pp 84-93.

Lowenthal ,Leo and Guterman, Norbert (1949) Prophets of Deceit:A Study of the Techniques of the American Agitator. New York ,Harper \& Bros.

McChung Lee, A and Briant-Lee, E (eds) (1939) The Fine Art of Propaganda: A Study of Father Coughlin's Speeches. New York .Harcourt-Brace.

Moffitt, Benjamin and Tormey,Simon (2014) 'Rethinking Populism : Politics, Mediatisation and Political Style', Political Studies, Vol 62, pp 381-397.

Neumann, Franz (1944) Behemoth: The Structure and Practice of National Socialism 1933-1944. [Second edition] Oxford. Oxford University Press. 
The Economist (2017) 'Leaders: Do social media threaten democracy?', The Economist, November $4^{\text {th }}, \mathrm{p} 11$ 